\title{
ANÁLISE CONSTITUCIONAL E HISTÓRICA DA PROTEÇÃO DA PROPRIEDADE E SUA FUNÇÃO SOCIAL NO BRASIL FRENTE À PROIBIÇÃO DO USO DE PLATAFORMAS DIGITAIS DE LOCAÇÃO EM CONDOMÍNIOS
}

\section{CONSTITUTIONAL AND HISTORICAL ANALYSIS OF PROTECTION OF PROPERTY AND ITS SOCIAL FUNCTION IN BRAZIL IN FRONT OF THE PROHIBITION OF THE USE OF DIGITAL RENTAL PLATFORMS IN CONDOMINIUMS}

\author{
Élcio Nacur Rezende ${ }^{1}$ \\ Josiane Oliveira de Freitas ${ }^{2}$
}

\begin{abstract}
RESUMO: O presente artigo, respaldado pelo método dedutivo, analisa suposta divergência de direitos promovida pela Constituição de 1988 quanto à proteção a propriedade e a sua função social, e ainda sua aplicação em condomínios edilícios nos quais, a defesa à segurança da coletividade, utilizada com fundamento no cumprimento da função social da propriedade, justifica a proibição do uso de plataformas digitais de locação. Para tanto, utilizou-se da pesquisa bibliográfica, qualitativa objetiva para verificar se de fato a proteção à função social da propriedade, previsto constitucionalmente, é argumento válido a justificar referida proibição. Por fim, conclui-se que para além da proteção constitucional dos referidos direitos, a proporcionalidade e a ponderação devem ser utilizadas para a resolução dos citados confrontos em condomínios.
\end{abstract}

Palavras-chave: Constituição; Propriedade; Função Social Propriedade; Condomínios.

ABSTRACT: This article, supported by the deductive method, analyzes the supposed divergence of rights promoted by the 1988 Constitution regarding the protection of

\footnotetext{
1 Doutor e Mestre em Direito. Professor dos programas de pós-graduação em direito da Escola Superior Dom Helder Câmara, Belo Horizonte - MG e das Faculdades de Direito Milton Campos (FDMC), Nova Lima - MG. E-mail: elciorezende@yahoo.com.br

${ }^{2}$ Mestranda pela Faculdade de Direito Milton Campos, Nova Lima - MG, especialista em Direito Civil, Advogada. E-mail: josiane.ofreitas@gmail.com
} 
property and its social function, as well as its application in building condominiums in which, the defense of the collective security, used with foundation in fulfilling the social function of the property, it justifies the prohibition on the use of digital rental platforms. For that, we used the objective qualitative bibliographic research to verify if in fact the protection to the social function of property, constitutionally provided for, is a valid argument to justify this prohibition. Finally, it is concluded that in addition to the constitutional protection of these rights, proportionality and weighting should be used to resolve the aforementioned conflicts in condominiums.

Keywords: Constitution; Property; Social Function Ownership; Condominiums.

Sumário: 1. Introdução; 2. O Condomínio Edilício - breves considerações; 3. Locação de imóveis por meio de plataformas digitais; 4. Do direito de propriedade; 4.1. Do direito de propriedade e seu tratamento constitucional; 5. Da função social da propriedade; 6 . Conclusão; 7. Referências

\section{INTRODUÇÃO}

O tema central deste estudo versa sobre recorrentes debates a respeito da proibição do uso de plataformas digitais de locação de imóveis em condomínio, com justificativa na segurança da coletividade. O fundamento de referida proteção se estabelece no uso da propriedade bem como na função social da propriedade, direitos previstos constitucionalmente.

A Constituição Federal de 1988 elencou, no artigo 5º , como direito fundamental a inviolabilidade ao direito de propriedade e ainda a função social da propriedade, sem, contudo, delimitar qual o conteúdo e profundidade de defesa deste último.

A função social da propriedade é citada em diversas oportunidades na Magna Carta de 1988, seja associada à propriedade rural, seja vinculada à urbana. O que se observa é que a carta constitucional, apesar de não definir o que seria considerada a função social da propriedade, relaciona está ao uso objetivando atender critérios econômicos e sociais. Contudo, a lei maior não a relaciona a questões de vizinhança.

O direito de propriedade em condomínios é tema controverso, em virtude da natureza complexa da propriedade, em razão de ser considerada exclusiva quanto à unidade autônoma e também mista no que diz respeito às partes comuns do edifício. Em condomínios, a função social da propriedade se relaciona com o direito ao sossego 
e a segurança da coletividade, o que enseja a objeção ao uso da propriedade para certos fins.

Justifica-se o presente estudo ante a necessidade de compreender a abrangência do direito de propriedade e de sua função social que a Constituição de 1988 buscou resguardar e em qual aspecto poderia ou não ser utilizado em condomínios no tocante às restrições ao uso da propriedade, como nos casos de locação via plataformas digitais como o Airbnb.

Com o advento da internet e a facilitação das relações sociais a locação de imóveis, por plataformas digitais, passou a ser utilizada com frequência, o que implica em alta rotatividade de pessoas com acesso a condomínios edilícios residenciais cujas unidades ou parte delas são alugadas por prazos exíguos e para uma infinidade de indivíduos.

O problema objeto de análise consiste em verificar, em razão da evolução histórica, qual a amplitude e conteúdo do direito de propriedade a Constituição de 1988 trouxe para o ordenamento jurídico brasileiro, a partir do qual se construiu o instituto da função social. A partir dessa análise tem-se a verificação da possibilidade de aplicação da função social da propriedade em relações de vizinhança, em especial nos condomínios edilícios, bem como a viabilidade de referido instituto justificar a proibição do uso de plataformas digitais de locação.

Em razão disso, a metodologia utilizada para a construção da pesquisa assentouse no método dedutivo, através de consulta bibliográfica, histórica, em artigos científicos e livros.

O referencial teórico utilizado baseou-se no entendimento de Farias e Rosenvald de que, não obstante, o regramento próprio existente em condomínios, é necessário discernimento de modo que as normas não se confrontem com a garantia fundamental do direito de propriedade que se relaciona com a função social. Além de assentar-se na Teoria da Cooriginalidade ou da Equiprimordialidade de direitos fundamentais de Habermas, posto que a propriedade é condição de possibilidade para a existência da função social da propriedade. 
Diante disso, demonstrou-se a necessidade de não analisar o direito de propriedade de forma isolada, assim, em atenção a equiprimordialidade dos direitos fundamentais, considera-se o dever de, mediante análise, ponderar a proporcionalidade da proibição do uso da propriedade em condomínios para fins de locação, através de plataformas digitais, em decorrência da conjugação de conceitos como direito a propriedade e sua função social.

\section{O CONDOMÍNIO EDILÍCIO - BREVES CONSIDERAÇÕES}

Ensinam Farias e Rosenvald (2015, p.601) que a expressão, condomínio edilício, é um neologismo, como condomínio que resulta da edificação. Anteriormente tratado em legislação específica, com o advento do Código Civil de 2002 o regramento sobre os condomínios edilícios, passou a ser abordado nos artigos 1.331 a 1.358 de referida lei. Da leitura do artigo 1.331 do CC se depreende que o Condomínio Edilício é a edificação que possuí partes que são de propriedade exclusiva e outras que são de propriedade comum.

Nesse ínterim, Farias e Rosenvald (2015, p.601) lecionam que:

(...) No condomínio edilício, ao reverso, os condôminos consideram-se, ao mesmo tempo, titulares exclusivos das unidades autônomas (proprietários individuais sobre partes exclusivas) e cotitulares das partes comuns. (...) Isto é, há uma verdadeira fusão entre propriedade particular e a propriedade comum, sendo impossível separar juridicamente esse complexo incindível.

Da leitura do artigo 1.331 do Código Civil é possível observar que não há uma definição específica sobre o que é considerado condomínio, tampouco acerca de sua natureza jurídica. $\mathrm{O}$ que se depreende de referido artigo é que a natureza jurídica poderia estar vinculada a questão da propriedade. Assim entende o doutrinador, Élcio Nacur Rezende (2004, p. 22): 
Verdadeiramente, a conjugação entre a propriedade exclusiva das unidades autônomas e a co-propriedade das partes comuns, melhor tem explicitado a natureza jurídica do condomínio.

Em continuidade a análise de referido artigo, as partes exclusivas são as unidades autônomas, ou seja, os apartamentos, já as porções comuns são aquelas que são utilizadas por todos os condôminos, tais quais escadas, elevadores, acesso aos logradouros públicos, dentre outros.

Nesse ínterim, a propriedade em um condomínio é entendida como dúplice, uma vez que aquele que adquire unidade autônoma no Edifício, também tem direito as áreas comuns, ou seja, há propriedade de parte exclusiva (apartamento) e de parte comum (áreas comuns), apesar de que nesta última o direito de propriedade é um pouco limitado, já que a fração ideal não poderá ser alienada ou dividida.

O Condomínio edilício pode ser entendido também como propriedade complexa, conforme ensinamento de Rezende (2004, p.25), visto que é "mista em relação às partes comuns e exclusiva em relação à parte autônoma".

Justamente essa duplicidade de propriedades em uma mesma edificação é o que dá ensejo a conflitos em condomínios, vez que, aquele que possui sua unidade autônoma exclusiva, quer dela se utilizar da forma que melhor lhe aprouver, porém, muita das vezes, tem seus direitos tolhidos em prol de uma coletividade que também reside naquele condomínio, é inclusive o caso tratado no presente artigo, quando há proibição da locação do apartamento via plataformas digitais.

Com a instituição do condomínio deve ser definido o fim a que as unidades se destinam, nos termos do artigo 1.332, III do CC, ou seja, quando o condomínio passa a ter existência deve-se definir se será utilizado para fins residenciais ou comerciais, ou ainda, para ambos os escopos, finalidades estas mais comuns dos condomínios nos dias atuais.

A respeito da finalidade, entende-se que uma vez instituído o condomínio e escolhida a destinação precípua daquele, não é possível sua utilização para outros fins. Assim, se foi instituído com o fim exclusivamente comercial, não é possível alugar 
uma sala e ali estabelecer residência, de outro modo, se a instituição foi para fins residenciais, não é viável comprar um apartamento e montar um escritório ou, como será tratado neste artigo, utilizar do imóvel residencial com fito de locação via plataforma digital.

O documento originário de um Condomínio Edilício é a Convenção de Condomínio, nela são tratados todos os aspectos importantes tais quais as frações ideais, a existência de vagas de garagem como propriedade autônoma ou ainda lugares para estacionamento, além das normas de convivência. Assim, a Convenção de Condomínio, segundo Farias e Rosenvald (2015, p.613):

\begin{abstract}
Trata-se de norma interna na qual são estipulados os direitos e deveres recíprocos dos condôminos. Seria uma espécie de constituição privada dos comproprietários, haja vista a sua força cogente apta a pautar comportamentos individuais reguladores da convivência geral. (...) O perfil da convenção é estatutário, trata-se de ato regra. O seu caráter normativo pode ser aferido pela aptidão para alcançar não apenas aqueles que deram a sua aprovação, mas também todos aqueles que futuramente ingressarem no condomínio, na condição de adquirentes, locatários e promissários compradores. (...) No direito real do condomínio edilício, não prevalece o acordo das partes, mas a sujeição de uma comunidade ao regime próprio instituído pela convenção.
\end{abstract}

Apesar de ser tida como constituição privada dos coproprietários é necessária cautela quando da elaboração das normas a serem seguidas dentro de um condomínio, isso porque, apesar de as questões serem tratadas coletivamente, em atenção a existência da copropriedade, há também a propriedade exclusiva das unidades autônomas, que merece regramento apto a garantir o exercício dos direitos do proprietário. Nesse sentido é o ensinamento de Farias e Rosenvald (2015, p.617):

Obtempere-se que a convenção condominial não poderá criar restrições indevidas aos condôminos, pois as limitações só se justificam quando correspondem à aplicação do princípio genérico que atende ao bem comum e impede o mau uso da propriedade nas relações de vizinhança, por ofensa à saúde, à segurança e ao sossego dos demais condôminos (art. 1.277 do CC). Ou seja: a convenção é a lei interna a ser observada por todos, mas as suas disposições devem guardar um mínimo de bom senso, sob pena de restrição à garantia fundamental ao direito de propriedade (art. $5^{\circ}, \mathrm{XXII}$, da CF). 
Não obstante, a eleição de síndico a quem compete à administração, representação do condomínio perante órgãos públicos e até mesmo em ações judiciais, dentre outras atribuições previstas no artigo 1.348 do Código Civil, todas as decisões quanto às questões condominiais, são tomadas pela massa condominial, ou seja, o conjunto de condôminos, desde que cumprido o quórum competente previsto em lei ou ainda na convenção de condomínio.

Assim, dentro do condomínio a assembleia de condôminos é soberana em todas as suas decisões, o que implica em dizer que, aquilo que for decidido em reunião de condôminos em observância ao quórum específico, deve ser cumprido por todos os outros, mesmo que não tenham anuído àquela decisão.

Todavia, nem tudo aquilo que for decidido em assembleia e que passe a constar do texto da convenção de condomínio deve obrigatoriamente ser cumprido por todos, isso porque, "as cláusulas que não guardarem harmonia com a Constituição Federal e ainda a razoabilidade serão consideradas como abuso do direito, ofendendo a finalidade para qual se instituiu o condomínio”. Farias e Rosenvald (2015, p.617).

Nesse sentido, tem sido comum em condomínios, o estabelecimento de normas, seja via assembleia de condôminos ou até mesmo por previsão em convenção de condomínio, que proíbam a locação de apartamentos dentro daquele Condomínio Edilício, por plataformas digitais tais quais, a título de exemplo, o Airbnb.

Referidas proibições encontram respaldo na proteção a segurança tendo como fundamento a função social da propriedade, direito previsto constitucionalmente no artigo $5^{\circ}$ da Constituição Federal de 1988.

Entretanto, o inciso primeiro do artigo 1.335 do Código Civil dispõe que dentre os direitos do condômino - leia-se o proprietário ou aqueles que a ele é equiparado, nos termos do $\S 2^{\circ}$ do artigo 1.334 do CC - estão o de usar, fruir e livremente dispor das suas unidades autônomas.

Os direitos de usar e fruir vão além do simples uso direto da unidade para fins de residência, não se desconsidera a importância de observância dos direitos da 
coletividade no tocante ao sossego e segurança, todavia, a limitação abusiva do direito de propriedade pode ser notada como tirania da vontade da maioria.

Assim, a proibição do uso de plataformas digitais de locação deve ser sopesada em um condomínio, exercendo a ponderação entre os direitos constitucionais à propriedade e à sua função social de forma a permitir o exercício de ambos os direitos nos conflitos em condomínios.

\section{LOCAÇÃO DE IMÓVEIS POR MEIO DE PLATAFORMAS DIGITAIS}

O direito subjetivo de propriedade concerne à relação jurídica complexa que se forma entre aquele que detém a titularidade formal do bem (proprietário) e a coletividade de pessoas (FARIAS E ROSENVALD, 2015, p. 217).

Dentre as faculdades inerentes ao proprietário, há a de usar, gozar e dispor da coisa, além do direito de reavê-la do poder de quem quer que injustamente a possua ou detenha nos termos do artigo 1228 do Código Civil (BRASIL, 2002).

Apesar de o uso de propriedade residencial ser, a primeiro momento, para fins de domicílio, o aproveitamento do bem imóvel como objetivo de auferir renda com o aluguel também é utilizado na sociedade brasileira, tanto assim o é que foi promulgada a Lei nº 8.245/1991 visando regular a locação de imóveis urbanos.

Por métodos tradicionais, a locação de imóveis urbanos era realizada ou diretamente com o proprietário, ou ainda mediante empresa especializada em tal serviço, como as imobiliárias. Em ambas as locações, elaborava-se contrato escrito indicando as partes, objeto da transação, duração, formas de pagamento, índices de correção dentre outros.

Apesar de a lei do inquilinato não dispor sobre o prazo mínimo para locação de imóveis urbanos, referidos acordos costumavam ser firmados por período não inferior a um ano, com possibilidade de prorrogação, tempo menor que este se dava apenas nos contratos de locação por temporada, em que o termo máximo deveria ser de até noventa dias. 
Com o advento da internet, viver em comunidade passou a novo trâmite, relações que eram engessadas a formalismos, elaboração de contratos e obrigatoriedade da pessoalidade, passaram a ser mais facilitadas, se antes era preciso ir a uma imobiliária para arrendar um imóvel, hoje plataformas digitais distintas fornecem a possibilidade de escolha de imóveis por região, preço, dentre outros critérios.

Não somente a forma de obtenção de informações quanto a imóveis colocados à locação mudou como também os parâmetros para esta, o aluguel de um imóvel deixou de ser por prazo mínimo de doze meses, ou termo de 90 dias como nos casos de locação por temporada, para prazos mínimos de meses, dias e até mesmo horas.

É o que se observa da utilização de plataformas digitais como o Airbnb que oferecem imóveis no Brasil e no mundo para uso por dias, horas ou meses. Além de encurtar o prazo mínimo de locação, referidas plataformas também modificaram seu conteúdo, aquela não está mais atrelada ao imóvel em sua integralidade, hoje é possível alugar um imóvel inteiro, um ou até alguns cômodos da edificação. Há casos inclusive em que o proprietário do imóvel convive com aqueles que o locaram por tais plataformas.

O Airbnb se define como uma comunidade baseada no compartilhamento, concedendo a anfitriões e a viajantes que procuravam um lugar para ficar, a possibilidade de anunciar seu espaço, para aqueles, e a de reservar acomodações únicas em qualquer localidade do mundo, para estes. Complementando a definição, o Airbnb:

(...) é um mercado online que permite aos usuários cadastrados ("Membros"), e terceiros determinados, que oferecem serviços (Membros e terceiros que oferecem serviços são chamados de "Anfitriões" e os serviços que eles prestam são "Serviços de Anfitrião"), anunciar esses Serviços de Anfitrião na Plataforma Airbnb ("Anúncios"), comunicar-se e fazer transações diretas com membros que estejam buscando reservar como Serviços de Anfitrião (os Membros que utilizam os Serviços de Anfitrião são chamados de "Hóspedes"). Os Serviços de Anfitrião podem incluir a oferta de propriedades destinadas a férias ou outros usos ("Acomodações"), atividades de um ou de múltiplos dias em diversas categorias 
("Experiências"), acesso a eventos e locais únicos ("Eventos"), e diversos outros serviços relacionados ou não à viagem. ${ }^{3}$

A plataforma garante que os serviços prestados são confiáveis, uma vez que há investigação dos perfis pessoais e dos anúncios, o que inclui verificação se os anfitriões e hóspedes constam de listas de observação de infrações regulatórias, terrorismo e sanções. ${ }^{4}$

Segundo a plataforma todos os riscos nas reservas são avaliados antes de serem confirmadas, através de tecnologias recentes de análise preditiva e aprendizado de máquina que analisa instantaneamente centenas de sinais que indiquem que uma atividade possa ser suspeita, antes que ela aconteça.

Os perfis tanto de hóspedes quanto de anfitriões são cadastrados com informações como nome completo, data de nascimento, número de telefone, dados de pagamento, mensagem de apresentação e endereço eletrônico. Segundo a plataforma a obtenção de tais informações auxilia na identificação de quem está oferecendo o imóvel em locação e daquele que faz a reserva.

Além disso, segundo a plataforma digital, aquele que oferece seu imóvel para reserva conta com uma proteção de até um milhão de dólares em caso de danos a propriedade e/ou prejuízos causados pelos hóspedes. Todavia, quanto aos danos a áreas comuns ou compartilhadas em prédios, segundo a plataforma digital, não há garantia. ${ }^{5}$

Feita uma breve introdução a respeito de pontos relevantes sobre condomínios e em que consiste a plataforma digital do Airbnb cumpre tratar sobre o direito de propriedade.

\section{DO DIREITO DE PROPRIEDADE}

\footnotetext{
3 Informação obtida dos Termos de Serviços do site Airbnb, mediante acesso ao link: https://www.airbnb.com.br/terms\#noneu. Acesso em 08 mai. 2020.

${ }^{4}$ Informações obtidas do site do AIRBNB, mediante acesso ao link: https://www.airbnb.com.br/trust. Acesso em: 09 mai.2020.

5 Informação obtida dos Termos e Condições de Garantia ao anfitrião mediante acesso ao link: https://www.airbnb.com.br/guarantee Acesso em: 09 mai.2020.
} 
A propriedade em seu significado básico se refere àquilo que pertence a alguém ${ }^{6}$, pode estar relacionada a bens móveis, imóveis, materiais e imateriais. Do conceito inicial de propriedade há todo um arcabouço jurídico que envolve referido direito, tal como a intelectual, industrial, até mesmo a de imóveis como é discutido no presente artigo.

Cumpre em primeiro momento, fazer uma breve digressão para tratar sobre a evolução histórica do direito de propriedade.

Nas sociedades primitivas, o solo pertencia a toda a coletividade, a propriedade naqueles tempos, se referia apenas aos bens de uso pessoal, tais como vestimentas, utensílios, dentre outros. O solo pertencia a todos e não havia o entendimento de que aquele lugar era de poder de apenas uma pessoa, referido aspecto talvez revele a primeira manifestação de função social da propriedade.

O direito romano foi o primeiro a tratar as coisas como se pertencessem a alguém, assim leciona Sílvio de Salvo Venosa (2019, p.262):

O Direito Romano cristalizou a ideia de que a res nullius pertence naturalmente ao primeiro tomador. A coisa é sem dono porque nunca o teve ou porque houve abandono por parte do titular (res derelicta). Efetiva-se a propriedade pela apreensão da coisa, com a intenção do agente de tê-la como própria.

Já na idade média, a propriedade começou a perder seu caráter de unitário, o território passa a ser sinônimo de poder. Assim, a ideia de propriedade se liga a soberania nacional.

Com o direito canônico, a propriedade privada é atrelada a ideia de liberdade individual, o homem está legitimado a adquirir bens.

O Código de Napoleão é que dá a propriedade o viés hoje conhecido e muitas vezes defendido em atenção à leitura simples do caput do artigo $5^{\circ}$ da Constituição, a

\footnotetext{
6 Definição retirada do dicionário Aulete, mediante consulta ao link: https://www.aulete.com.br/propriedade. Acesso em: 09 mai.2020
} 
propriedade como direito de gozar e dispor da coisa de modo mais absoluto desde que seu uso não seja proibido por lei ou regulamentos.

No século XIX, com a revolução industrial e as ideias de defesa dos direitos coletivos, foi iniciada a busca pelo sentido social da propriedade. Com a ideologia liberal e individualista passou-se a "conceder ao sujeito de direito a possibilidade de manifestar livremente a sua vontade, em um contexto econômico propício à circulação de capital." (FARIAS E ROSENVALD, 2015, p.213).

No Brasil, a propriedade privada imobiliária sofreu um longo processo de saída do patrimônio público para ingresso na esfera privada (FARIAS E ROSENVALD, 2015, p.214).

O Código Civil de 1916 estabelecia no artigo 524 que a lei asseguraria ao proprietário o direito de usar, gozar e dispor de seus bens, e de reavê-los do poder de quem injustamente os possua. Referido Código se baseava em doutrinas individualistas, consagradas pelo Código de Napoleão, que pregavam como valor fundamental o indivíduo.

Não há também conceito do que seria o direito de propriedade no Código Civil de 2002, este se limita, porém, a identificar as faculdades que o proprietário possui que são aquelas mesmas de gozar, usar, dispor da coisa e ainda de reavê-la, nos termos do artigo 1.228. Destaca-se ainda que o exercício do direito de propriedade deve observar às finalidades econômicas e sociais.

Do breve relato acima é possível notar que o direito de propriedade se amolda a cultura daquele momento, em razão disso, a propriedade pode ser entendida como uma instituição social, que apesar de estar positivada nas legislações, a depender do período histórico vivido, assume um papel específico.

\subsection{DO DIREITO DE PROPRIEDADE E SEU TRATAMENTO CONSTITUCIONAL}

As Constituições brasileiras, desde a primeira, trataram sobre o direito de propriedade em todos os textos, cada qual com uma verificação da propriedade de 
acordo com o contexto histórico da época e ainda, de qual profundidade de defesa desse direito era necessária.

A primeira Carta Maior brasileira, a Constituição do Império do Brasil de 1824, trazia em seu texto a seguinte previsão a respeito do direito de propriedade (SENADO, 2012, p. 85):

Art. 179. A inviolabilidade dos Direitos Civis, e Politicos dos Cidadãos Brazileiros, que tem por base a liberdade, a segurança individual, e a propriedade, é garantida pela Constituição do Imperio, pela maneira seguinte.

(...)

XXII. E'garantido o Direito de Propriedade em toda a sua plenitude. Se o bem publico legalmente verificado exigir o uso, e emprego da Propriedade do Cidadão, será elle préviamente indemnisado do valor della. A Lei marcará os casos, em que terá logar esta unica excepção, e dará as regras para se determinar a indemnisação.

A Constituição Política do Império do Brazil de 1824 foi outorgada por D. Pedro I, texto legal se inspirou no constitucionalismo inglês, para qual é considerado como constitucional apenas o que diz respeito às garantias individuais e os poderes do Estado.

Note que em 1824 o direito a propriedade era considerado como direito absoluto, uma vez que o proprietário poderia exercer o direito em toda sua plenitude, ou seja, de forma completa, assim, não havia limites a propriedade, não considerando os anseios sociais da coletividade.

Naquele tempo a propriedade sofria limitação apenas quanto à utilização do bem pelo Estado, mediante lei prévia e indenização. Esse conceito de propriedade plena ficou conhecido como "absolutização" do direito de propriedade, e se tornou um pressuposto do sistema político, econômico e social-liberal (LIMA E CARVALHO, 2013, p.36).

Cumpre frisar também, que "o direito de propriedade estava no mesmo patamar da importância dos valores de liberdade e segurança individual, noções que eram propagadas pelos movimentos liberais europeus. A garantia da propriedade individual 
se confrontava com os abusos cometidos pelas práticas absolutistas da monarquia (LIMA E CARVALHO, 2013, p.40)".

Além disso, a proteção à propriedade seria um instrumento apto a evitar que as revoluções iniciadas na Europa chegassem ao Brasil. Diante disso, a primeira constituição brasileira previa o direito a propriedade como direito absoluto e oponível a todos, a exceção do Estado.

Posteriormente, com a proclamação da República em 15 de novembro de 1889 e em razão de diversas mudanças sociais, políticas e econômicas no Brasil, foi necessário elaborar novo texto Constitucional.

A Constituição da República dos Estados Unidos do Brasil de 1891 resguardava o direito à propriedade nos seguintes termos (SENADO, 2012, p.81):

Art. 72. A Constituição assegura a brasileiros e a estrangeiros residentes no paiz a inviolabilidade dos direitos concernentes á liberdade, á segurança individual e á propriedade nos termos seguintes:

(...)

$\S 17$. O direito de propriedade mantem-se em toda a sua plenitude, salva a desapropriação por necessidade, ou utilidade publica, mediante indemnisação prévia.

Da análise de referido texto, nota-se que não há muita mudança em relação à proteção constitucional da propriedade conforme era tratada anteriormente, é mantida a inviolabilidade dos direitos concernentes à propriedade e este direito se mantém em toda sua plenitude. É nítida a utilização da proteção anterior com a frase o direito de propriedade se mantém em toda sua plenitude, não se olvidando da possibilidade de intervenção do Estado na propriedade privada por meio da desapropriação, mediante indenização prévia.

O Brasil passou a ser visto como República se baseando na matriz constitucional norte-americana, a Constituição foi inspirada nos ideais republicanos e liberais (GROFF, 2008, p.108). Referida Constituição primou por estabelecer o presidencialismo, separação entre Estado e religião e, a independência dos três poderes em razão do fim do poder moderador. 
Com os movimentos revolucionários sociais que antecederam 1934 e a necessidade de implantação de um Estado Social, baseando-se na Constituição Alemã de Weimar, promulgou-se nova Constituição. Na Constituição de 1934 o direito de propriedade passa a ter o limite de lei e inicia-se o entendimento do uso da propriedade em observância ao social, determinando a impossibilidade de seu exercício contra o interesse social ou coletivo.

A Constituição da República dos Estados Unidos do Brasil de 1934 tratava sobre o direito de propriedade nos termos abaixo (SENADO, 2012, p. 130):

\begin{abstract}
Art. 113. A Constituição assegura a brasileiros e a estrangeiros residentes no paiz a inviolabilidade dos direitos concernentes á liberdade, á subsistencia, á segurança individual e á propriedade, nos termos seguintes:

17) E' garantido o direito de propriedade, que não poderá ser exercido contra o interesse social ou collectivo, na fórma que a lei determinar. A desapropriação por necessidade ou utilidade publica far-se-á nos termos da lei, mediante prévia e justa indemnização. Em caso de perigo imminente, como guerra ou commoção intestina, poderão as autoridades competentes usar da propriedade particular até onde o bem publico o exija, resalvado o direito a indemnização ulterior.
\end{abstract}

Das Constituições brasileiras esta é a primeira que não trata o direito a propriedade como absoluto e tampouco o exercício deste direito em sua plenitude. Em atenção aos direitos sociais, a Constituição de 1934 prevê a garantia do direito a propriedade, mas desde que não seja exercido contra o interesse social ou coletivo.

Há também inovação quanto à autorização para a intervenção do Estado na propriedade, além da possibilidade de desapropriação por necessidade ou utilidade pública, também é permitida a interferência em caso de perigo iminente como guerra, momento em que a propriedade particular pode ser usada pelo Estado, a indenização nesse caso, será ulterior. Referido acréscimo de intervenção do Estado, pode ter se embasado na Primeira Guerra Mundial.

A Constituição de 1934 foi responsável por introduzir direitos de segunda geração, ou seja, direitos culturais, sociais e econômicos.

Em 1937, revogando a Constituição de 1934, Getúlio Vargas outorgou a Constituição do Estado Novo, com base em inspiração fascista adotando medidas 
como supressão de partidos políticos, instituição de pena de morte, anulação da independência dos Poderes Legislativo e Judiciário; prisão e exílio dos opositores do governo, dentre outros.

A respeito do direito de propriedade, assim dispunha a Constituição dos Estados Unidos do Brasil de 1937 (SENADO, 2012, p.81):

Art. 122. A Constituição assegura aos brasileiros e estrangeiros residentes no paiz o direito á liberdade, á segurança individual e á propriedade, nos termos seguintes:

(...)

14 - O direito de propriedade, salvo a desapropriação por necessidade ou utilidade publica, mediante indemnização prévia. O seu conteúdo e os seus limites serão os definidos nas leis que lhe regularem o exercício.

Ao contrário das Constituições anteriores, a Constituição de 1937, não previu o direito a inviolabilidade do direito a propriedade, apenas assegurou referido direito, ou seja, garantiu esse direito aos brasileiros, porém, indicou que o conteúdo e os limites desse direito seriam definidos em leis que regularem o seu exercício.

Mencionada previsão dá ensejo ao questionamento, havia mesmo o direito de propriedade nos idos dos anos de 1937, quando da decretação da Constituição de 1937? Outro ponto de destaque é a supressão do resguardo ao direito de exercício da propriedade desde que não exercido contra direito coletivo ou social.

Sobre a proteção do direito de propriedade na Constituição outorgada de 1937, importante destacar entendimento de Assis (2008, p.787):

A Constituição outorgada, de 1937, restringe completamente o direito de propriedade aos termos da Lei, centralizando esse conceito e a disciplina desse direito nas mãos do presidente da República. O próprio conteúdo do direito de propriedade é desconstitucionalizado, passando a questão a ser tratada por leis inferiores.

Assim, a propriedade em 1937, apesar de supostamente assegurada pela Constituição, não podia ser exercida de forma plena, não se relacionava com exercício em prol do coletivo ou social e tinha conteúdo e limites delimitados por lei. 
A Constituinte de 1946, em um contexto de democratização do país, tentou restaurar o regime destruído pelo golpe de 1937, retomando as ideias de proteção aos trabalhadores, à ordem econômica, à educação e à família, que haviam sido iniciados em 1934 com a Constituição que previa uma gama de direitos voltados para o social e a coletividade, além do restabelecimento de direitos individuais como o de propriedade.

Retomando o caráter de inviolável, a Constituição dos Estados Unidos do Brasil de 1946 assim dispôs sobre o direito de propriedade (SENADO, 2012, p.82):

\begin{abstract}
Art. 141. A Constituição assegura aos brasileiros e aos estrangeiros residentes no país a inviolabilidade dos direitos concernentes à vida, à liberdade, à segurança individual e à propriedade, nos têrmos seguintes:

(...)

$\S 16$. E' garantido o direito de propriedade, salvo o caso de desapropriação por necessidade ou utilidade pública, ou por interêsse social, mediante prévia e justa indenização em dinheiro. Em caso de perigo iminente, como guerra ou comoção intestina, as autoridades competentes poderão usar da propriedade particular, se assim o exigir o bem público, ficando, todavia, assegurado o direito a indenização ulterior.
\end{abstract}

Em 1946 a propriedade volta a ter seu caráter de inviolável, salvo a possibilidade de desapropriação pelo Estado ou em caso de necessidade, ou utilidade pública e, inovando, com a desapropriação também por interesse social, todas mediantes prévias indenização.

Após o golpe de 1937 e com a restrição de inúmeros direitos que haviam sido conquistados com a Constituição de 1934, os liberais optaram por retomar a proteção de direitos sociais e a defesa da coletividade, motivo pelo qual foi criada a hipótese de desapropriação também por interesse social.

Ainda em razão dos temores de possível segunda guerra, retomou-se a possibilidade de uso da propriedade particular com indenização posterior, em caso de perigo iminente.

Além disso, a Constituição de 1946 retomou a ideia de uso da propriedade com um caráter mais coletivo, estabelecendo o uso da propriedade condicionado ao bem- 
estar social, não se olvidando da indicação da justa distribuição de propriedade, conforme se nota do excerto:

Art. 147. O uso da propriedade será condicionado ao bem-estar social. A lei poderá, com observância do disposto no art. 141, § 16, promover a justa distribuição da propriedade, com igual oportunidade para todos. (SENADO, 2012, p.86)

A Constituição, de 1967, tenta ser o protagonismo do Estado como agente de desenvolvimento econômico (ASSIS, 2008, p.788). Assim, a Constituição do Brasil de 1967 tratou sobre o direito à propriedade da seguinte forma (SENADO, 2012, p.188):

Art. 153. A Constituição assegura aos brasileiros e aos estrangeiros residentes no País a inviolabilidade dos direitos concernentes à vida, à liberdade, à segurança e à propriedade, nos têrmos seguintes:

(...)

$\S 22$. É garantido o direito de propriedade, salvo o caso de desapropriação por necessidade ou utilidade pública ou por interêsse social, mediante prévia e justa indenização em dinheiro, ressalvado o disposto no art. 157, VI, § 1 o . Em caso de perigo público iminente, as autoridades competentes poderão usar da propriedade particular, assegurada ao proprietário indenização ulterior.

Apesar de não constar junto ao direito de propriedade, o uso de forma não contrária aos direitos da coletividade, o artigo 157 da Constituição de 1967 estabelece a função social da propriedade como principio da ordem econômica, para realizar a justiça social, conforme se nota de excerto:

Art. 157. A ordem econômica tem por fim realizar a justiça social, com base nos seguintes princípios:

(...)

III - função social da propriedade; (SENADO, v. VI, 2012, p.126 e 127)

Assim, apenas a partir da Constituição de 1967 é que se passou a compreender que o uso da propriedade não poderia ser irrestrito e absoluto, devendo obedecer ao interesse coletivo, referido direito passa a ser percebido como necessário a um papel social e coletivista. 
Terminado o regime militar, foi elaborada nova Constituição em razão do processo de redemocratização do país de modo a expressar a contemporânea realidade social, ampliaram-se as liberdades civis, os direitos e garantias individuais.

Aos direitos fundamentais foi dada importância maior, uma vez que, ao contrário das Constituições anteriores em que a proteção aos direitos fundamentais estava apenas ao final do texto constitucional, na Constituição de 1988 está bem no início do texto, no título II, o que sugere o grau de relevância dado a referidos direitos pelo constituinte.

O direito de propriedade, na Constituição Federal de 1988, é tratado no título que trata sobre os direitos e garantias fundamentais, o caput do $\operatorname{artigo} 5^{\circ}$ da Constituição (BRASIL, 1988) garante a inviolabilidade do direito à propriedade, e o inciso XXII do mesmo artigo assegura aos brasileiros o direito de propriedade. Não se olvide que a propriedade constitui princípio da ordem econômica nos termos do art. 170, II da Constituição Federal.

A despeito da previsão do direito de propriedade como direito fundamental, é possível notar que a constituição também instituiu como direito fundamental, no inciso XXIII do artigo $5^{\circ}$, a função social da propriedade, que deveria balizar o uso daquela.

Desta feita, em razão da evolução histórica apontada neste tópico, nota-se que o direito de propriedade que antes era visto como direito absoluto e irrestrito, passou a ser pensado sob novo viés, um direito a ser exercido em prol de uma coletividade.

Assim, cumpre analisar o que se trata a função social da propriedade e se esta seria de fato justificativa apta à proibição do uso de plataformas digitais de locação de imóveis em condomínios.

\section{DA FUNÇÃO SOCIAL DA PROPRIEDADE}

Podemos assim conceituar a propriedade como uma relação jurídica complexa formada entre o titular do bem e a coletividade de pessoas. (FARIAS E ROSENVALD, 2015, p.217). 
Importante destacar o momento histórico vivido no país quando da promulgação da Constituição de 1988, o país havia acabado de sair de uma ditadura em que os direitos fundamentais haviam sido esquecidos, a individualidade era prioridade, cabia naquela ocasião retomar os direitos individuais, ditos fundamentais, mas também evidenciar o pensamento de uso dos direitos de forma social, pensando em uma coletividade.

O liberalismo econômico, muito presente no início do século $\mathrm{XX}$, ensejou a mudança a respeito do paradigma inicial do direito de propriedade, alcance e conteúdo de referido direito passaram a ser compreendidos de nova forma.

Diante disso, a propriedade além de satisfazer os interesses do proprietário, daquele que possuísse sua titularidade, deveria atender também às necessidades da coletividade, o que seria entendido como cumprir a função social.

No início do século XX Leon Duguit elabora conceito jurídico originário de função social da propriedade, para aquele jurista francês, a propriedade não pode ser vista como um caráter absoluto, além disso, não se pode dizer que nem o homem ou a coletividade têm direitos, o que se pode afirmar é que cada indivíduo possui uma função que deve ser cumprida na sociedade.

Sobre a função social da propriedade, assim entende Duguit (1975, p.178-179):

(...) a propriedade não tem mais um caráter absoluto e intangível, o proprietário, pelo fato de possuir riqueza (propriedade), deve cumprir sua função social. Os direitos de proprietário somente estão protegidos se ele cultivar a terra ou se não permitir a ruína de sua casa, caso contrário será legítima a intervenção do Estado para obrigar o cumprimento de sua função social. (Entendimento nosso do texto original).

O conceito de propriedade elaborado por Duguit compreende que de acordo com a revolução econômica, os conceitos de instituições jurídicas também devem evoluir, assim, ao elaborar o conteúdo da função social da propriedade, reconheceu que a partir do século $\mathrm{XX}$ todas as propriedades evoluíram de acordo com um sentido social. 
A concepção vigente de função social da propriedade teve nascedouro na Constituição alemã de Weimar, de 1919, referida constituição trouxe novo entendimento à concepção de propriedade, entendendo-a como relação jurídica complexa, na qual o proprietário além de usar do bem, tem deveres para com a coletividade. Assim, "valoriza-se a fraternidade em detrimento de uma igualdade meramente formal entre proprietários e não proprietários (FARIAS E ROSENVALD, 2015, p.260)".

$\mathrm{O}$ inciso XXIII do artigo $5^{\circ}$ da Constituição indica que apesar da garantia do direito de propriedade, esta deve atender a sua função social. Além disso, é principio da ordem econômica, a função social da propriedade, nos termos do inciso III do artigo 170 da Constituição Federal de 1988. Mas o que seria a função social da propriedade?

Farias e Rosenvald (2015, p.260) lecionam que:

\begin{abstract}
A locução função social traduz o comportamento regular do proprietário, exigindo que ele atue numa dimensão na qual realize interesses sociais, sem a eliminação do direito privado do bem que lhe assegure as faculdades de uso, gozo e disposição. Vale dizer, a propriedade mantém-se privada e livremente transmissível, porém detendo finalidade que se concilie com as metas do organismo social.
\end{abstract}

Assim, não se olvide que permanecem os atributos decorrentes da propriedade como o de usar, gozar e dispor da coisa, conforme previstos no artigo 1.228 e ainda, no que diz respeito aos condomínios edilícios, nos termos do artigo 1.335, I, ambos do Código Civil, contudo, para além desses direitos devem-se observar também os interesses sociais.

No tocante a função social da propriedade urbana, que se adéqua aos condomínios edilícios tratados no presente estudo, o $§ 2^{\circ}$ do artigo 182 da Constituição prevê como os imóveis urbanos cumprem sua função social, litteris:

Art. 182. A política de desenvolvimento urbano, executada pelo Poder Público municipal, conforme diretrizes gerais fixadas em lei, tem por objetivo ordenar o pleno desenvolvimento das funções sociais da cidade e garantir o bem-estar de seus habitantes.

(...) 
$\S 20$ A propriedade urbana cumpre sua função social quando atende às exigências fundamentais de ordenação da cidade expressas no plano diretor. (SENADO, v. VII, 2012, p.142)

O plano diretor é o documento básico dos municípios que descreve como será o desenvolvimento e a expansão urbana, tratando sobre o uso e ocupação do solo, das quais se destacam o parcelamento, a edificação ou utilização compulsórios, ou seja, a toda propriedade deve ser dada uma destinação específica para atender a função social.

Além disso, o plano diretor deve definir diretrizes e instrumentos sobre o uso da propriedade que visem à proteção ambiental e ainda o patrimônio histórico e cultural. É o que também prevê o $\$ 1^{\circ}$ do artigo 1.228 do Código Civil no que diz respeito à observação das referidas questões citadas anteriormente bem como ao atendimento das finalidades econômicas e sociais.

A propriedade que não é utilizada pelo proprietário e que em razão disso dá ensejo a diversos danos aos outros proprietários que residem próximos àquela propriedade não cumpre com sua função social.

A despeito da Constituição Federal não trazer o conceito do que seria a função social da propriedade, os artigos que a ela se referem indicam correlação com aspectos econômicos, atendimento de normas sobre utilização do espaço de forma a não causar danos ao meio ambiente, a terceiros, a desapropriação por parte do Estado, não estando vinculada a questões de vizinhança.

A vinculação da função social da propriedade ao direito de vizinhança foi trazida a legislação apenas no Código Civil de 2002, conforme se nota do previsto no $\S 1^{\circ}$ do artigo 1.228 , quanto ao condomínio vincula-se a função social ao mencionado no inciso IV do artigo 1.336 do Código Civil, no que diz respeito à utilização da unidade autônoma de maneira que não seja prejudicial ao sossego, salubridade e segurança dos possuidores ou ainda aos bons costumes.

A segurança dos coproprietários é utilizada como justificativa para proibição do uso de plataformas digitais de locação, tais como o Airbnb, em condomínios, alega-se que pela alta rotatividade de pessoas o condomínio fica vulnerável. Todavia, ao alegar 
tal fato, ocultam a análise da locação por temporada que possui previsão legal na lei do inquilinato.

Naquela modalidade de locação, o proprietário pode alugar o imóvel por prazo não superior a 90 dias, ou seja, trata-se de locação por curto período. O que de fato se observa não é a preocupação com a segurança, pois se assim o fosse não se admitiria tampouco a locação por temporada. A questão relacionada ao aluguel por plataformas digitais vai além, não configurando afronta a função social da propriedade.

Os Tribunais brasileiros têm caminhado no sentido de utilizar a ponderação no caso concreto e verificar a proporcionalidade utilizada em caso de restrição de direitos fundamentais, tais como o direito de propriedade. A proibição do uso de plataformas digitais é proporcional à defesa da segurança dos condôminos? É razoável proibir a locação via plataformas digitais, mas não proibir a locação por temporada?

Jane Reis Gonçalves Pereira, assim define a ponderação (2018, p.305):

O vocábulo ponderação, em sua acepção mais corrente, significa a operação hermenêutica pela qual são contrabalançados bens ou interesses constitucionalmente protegidos que se apresentem em conflito em situações concretas, a fim de determinar, à luz das circunstâncias do caso, em que medida cada um deles deverá ceder ou, quando seja o caso, qual deverá prevalecer.

Como visto acima, o direito a propriedade e ainda sua função social são elencados no rol de direitos fundamentais previstos no artigo $5^{\circ}$ da Constituição, no conflito de interesses entre o exercício do direito de propriedade, uso do Airbnb, e ainda a aplicação da função social, proibição como garantia a segurança dos demais coproprietários, deve-se ponderar os direitos em análise para verificar qual deveria prevalecer.

Não há exclusão do rol de direitos fundamentais em caso de aplicação de um direito em detrimento do outro, o que de fato se observa é a necessidade de contrabalancear os direitos com a finalidade de chegar a uma decisão que seja favorável a ambas as partes. 
Assim, se a proibição ao uso de plataformas digitais de locação, como o Airbnb $b_{s}$ em condomínios se justifica em razão ao exercício da função social no que diz respeito a não trazer risco a segurança dos demais, usando-se da ponderação seria possível permitir ao proprietário direito de uso do bem, mesmo que para tal locação, resguardando a segurança dos demais coproprietários ao estabelecer a necessidade de cadastro de informações dos locadores das unidades bem como indicação para o Condomínio do lapso temporal de referida locação.

A ponderação identifica-se com o princípio da proporcionalidade, uma vez que serão equacionados "os ônus e as vantagens que defluem da tutela total ou parcial de cada um dos bens jurídicos em conflito (PEREIRA, 2018, p. 310)”.

Nesse sentido, não há que se falar em abstenção do direito de propriedade, direito individual, para se falar em aplicação da função social da propriedade, direito em prol do coletivo, posto que a propriedade é condição de possibilidade para a existência da função social da propriedade, é o que Habermas chamou de cooriginalidade (ou de equiprimordialidade).

Assim, Habermas entende que o espaço coletivo bem como as liberdades individuais possuem ponto de convergência entre si, ou seja, cada qual tem seu grau de importância a depender do contexto e ainda do pano de fundo normativo.

Nesse ínterim, entende Habermas (2004, p. 293 e 294) que:

(...) a autonomia privada e a pública pressupõem-se mutuamente, sem que os direitos humanos possam reivindicar um primado sobre a soberania popular, nem essa sobre aquele. (...) os cidadãos só podem fazer um uso adequado de sua autonomia pública quando são independentes o bastante, em razão de uma autonomia privada que esteja equanimemente assegurada; mas também no fato de que só poderão chegar a uma regulamentação capaz de gerar consenso, se fizerem uso adequado de sua autonomia política enquanto cidadãos de Estado.

Em atenção ao pensamento supracitado e ao presente estudo, compreende-se que não é possível justificar a proibição do uso de plataformas digitais em relação à violação a função social da propriedade, uma vez que o direito coletivo só pode ser 
defendido partindo de um direito individual que também está assegurado. "O direito legitima-se dessa maneira como um meio para o asseguramento equânime da autonomia pública e privada (HABERMAS, 2004, p.291).”

\section{CONCLUSÃO}

O direito a propriedade no arcabouço jurídico brasileiro sofre transformações desde os idos do Brasil Império em que referido direito deveria ser utilizado em toda sua plenitude, sem quaisquer intervenções de terceiros ou ainda do Estado.

O direito a propriedade, a cada período histórico vivido no Brasil assumia uma nova vertente, chegando a ser reconhecido como direito em prol do coletivo a partir da carta constitucional de 1946, e consagrando a função social da propriedade com o advento da Constituição Federal de 1988.

A Constituição Cidadã, após o período militar em que alguns direitos fundamentais foram olvidados, buscou trazer à legislação do país a ideia de direitos pensados em prol de uma coletividade, direitos em prol do social.

Do estudo realizado notou-se que, apesar de ser citada em inúmeras oportunidades, na Carta Magna de 1988, a função social da propriedade não foi atrelada ao direito de vizinhança, o texto constitucional vincula a função social da propriedade a questões econômicas e ainda em relação ao uso da propriedade, que no caso da urbana, deve observar o plano diretor.

Assim, constatou-se que a associação da função social ou ainda da defesa de um aspecto social da propriedade relacionada ao direito de vizinhança, é trazida pelo Código Civil de 2002, que impõe ao proprietário direito de usar o bem desde que em consonância com as questões sociais e em respeito à segurança, sossego e bons costumes.

Ainda assim, do estudo elaborado nota-se que o legislador não optou por definir o que seria considerado como função social da propriedade, apenas indicou os caminhos a serem seguidos a fim de alcançar suposta função social. 
A proibição do uso de plataformas digitais de locação em condomínios, muita das vezes, tem como embasamento a violação a função social da propriedade no que diz respeito ao não resguardo dos condôminos quanto à segurança.

A partir do estudo elaborado, tem-se que não há que se falar em direito absoluto, seja o direito a propriedade, seja a função social. Da leitura do $\operatorname{artigo~} 5^{\circ}$ da Constituição Federal, percebe-se que tanto um direito quanto o outro são elencados como fundamentais.

Desse modo, a vedação ao uso de plataformas como o Airbnb em condomínios não é o caminho adequado, ponderando os direitos em análise, considera-se que não há proporcionalidade em referida oposição.

Assim, tem-se que a partir do direito de propriedade e de sua função social, a forma de resolução do entrave seria mediante um agir comunicativo dos envolvidos, o que permitiria não a sobreposição do direito coletivo em detrimento do direito individual, mas sim uma adequação de interesses de ambas as partes de forma a garantir o uso da propriedade, mas também, a segurança da coletividade dos condôminos.

Por todo o exposto, a oposição ao uso de plataformas digitais de locação em condomínios edilícios fundamentada na segurança dos condôminos e respaldada na função social da propriedade, não é constitucional, uma vez que a Carta Magna de 1988 não relacionou aquela ao direito de vizinhança.

Considerando que tanto o direito à propriedade quanto sua função social estão elencados no rol de direitos fundamentais, ambos devem ser exercidos dentro de um Condomínio. Deste modo, deve ser permitido o uso de plataformas digitais como o Airbnb em condomínios, em atenção ao direito de propriedade.

E, quanto à segurança dos condôminos, a implantação de regras de convivência que indiquem ao condômino, cadastrado em tais plataformas, a necessidade de informar ao condomínio quem está ocupando o imóvel e por qual período, trará a tão sonhada segurança para a massa condominial e não impedirá o proprietário da unidade autônoma de utilizar-se do seu bem. 


\section{REFERÊNCIAS}

AIRBNB. O que é o Airbnb e como ele funciona? Airbnb, Inc. 2020. EUA. Disponível em: https://www.airbnb.com.br/help/article/2503/o-que-\%C3\% A9-oairbnb-e-como-ele-funciona. Acesso em: 05 mai. 2020.

AIRBNB. Termos de Serviços Airbnb. Inc. 2020. EUA. Disponível em: https://www.airbnb.com.br/terms\#noneu. Acesso em: 20 maio. 2020.

ASSIS, Luis Gustavo Bambini de. Evolução do direito de propriedade ao longo dos textos constitucionais. Revista da Faculdade de Direito, Universidade de São Paulo, v. 103, p. 781-791, 1/jan. 2008.

BALEEIRO, Aliomar. Coleção Constituições brasileiras; v. II - 3 ed. - Brasília: Senado Federal, Subsecretaria de Edições Técnicas, 2012. Disponível em: https://www2.senado.leg.br/bdsf/bitstream/handle/id/137570/Constituicoes_Brasileiras _v2_1891.pdf?sequence=5. Acesso em: 20 maio. 2020.

BALEEIRO, Aliomar; SOBRINHO, Barbosa Lima. Coleção Constituições brasileiras; v. V - 3 ed. - Brasília: Senado Federal, Subsecretaria de Edições Técnicas, 2012. Disponível em: http://www2.senado.leg.br/bdsf/bitstream/handle/id/139953/Constituicoes_Brasileiras _v5_1946.pdf?sequence=9). Acesso em: 21 mai. 2020.

BRASIL. Constituição da República Federativa do Brasil. Brasília, DF: Senado Federal, $1988 . \quad$ Disponível em: http://www.planalto.gov.br/ccivil_03/constituicao/constituicao.htm. Acesso em: 25 abr. 2020.

BRASIL. Lei $\mathrm{n}^{\mathrm{o}} 10.406$ de 10 de janeiro de 2002. Institui o Código Civil. 2002. In: Diário Oficial da República Federativa do Brasil, Brasília, DF, 11 jan.2002. Disponível em: http://www.planalto.gov.br/ccivil_03/leis/2002/L10406compilada.htm. Acesso em: 23 abr. 2020.

CAVALCANTI, Themístocles Brandão; BRITO, Luiz Navarro; BALEEIRO, Aliomar. Coleção Constituições brasileiras; v. VI - 3 ed. - Brasília: Senado Federal, Subsecretaria de Edições Técnicas, 2012. Disponível em: https://www2.senado.leg.br/bdsf/bitstream/handle/id/137603/Constituicoes_Brasileiras _v6_1967.pdf?sequence=9\&isAllowed=y. Acesso em: 21 mai. 2020.

DUGUIT, Leon. Las transformaciones del Derecho Publico y Privado. Buenos Aires: Editorial Heliasta S.R.L., 1957. 
FARIAS, Cristiano Chaves de; ROSENVALD, Nelson. Curso de Direito Civil; v. 5 11. ed. rev., ampl. e atual. - São Paulo: Atlas, 2015.

GROFF, Paulo Vargas. Direitos Fundamentais nas constituições brasileiras. Revista de informação legislativa, v. 45, n.178, p.105-129, abr./jun. 2008, 04/2008. Disponível em: https://www2.senado.leg.br/bdsf/handle/id/176526. Acesso em: 20 mai. 2020.

HABERMAS, Jürgen. A inclusão do outro - estudos da teoria política. Tradução: George Sperber, Paulo Astor Soethe (UFPR). São Paulo: Edições Loyola, 2002.

JELINEK, ROCHELLE. O princípio da função social da propriedade e sua repercussão sobre o sistema do código civil. UFRGS, Porto Alegre, 2006. Disponível em: https://www.mprs.mp.br/media/areas/urbanistico/arquivos/rochelle.pdf. Acesso em: 20 mai.2020.

LEAL, Roger Stiefelmann. A propriedade como direito fundamental: breves notas introdutórias. Revista de Informação Legislativa, Brasília, v. 49, n. abr./ju 2012, p. 53-64, 2012.

LIMA, Elisberg Francisco Bessa Lima; CARVALHO, Melissa Morais Falcão de Carvalho. A concepção do direito de propriedade na constituição política do império do Brasil. CONPEDI/UNINOVE; Coordenadores: Giordano Bruno Soares Roberto, Gustavo Silveira, Ricardo Marcelo Fonseca - Florianópolis: FUNJAB, 2013. Disponível em: http://www.publicadireito.com.br/publicacao/uninove/livro.php?gt=25. Acesso em: 20 mai. 2020.

NOGUEIRA, Octaciano. Coleção Constituições brasileiras; v. I - 3 ed. - Brasília: Senado Federal, Subsecretaria de Edições Técnicas, 2012. Disponível em: https://www2.senado.leg.br/bdsf/bitstream/handle/id/137569/Constituicoes_Brasileiras _v1_1824.pdf. Acesso em: 25 abr. 2020.

PEREIRA, Jane Reis Gonçalves. Interpretação constitucional e direitos fundamentais - 2. ed. - São Paulo: Saraiva Educação, 2018.

POLETTI, Ronaldo. Coleção Constituições brasileiras; v. III - 3. ed. - Brasília: Senado Federal, Subsecretaria de Edições Técnicas, 2012. Disponível em: https://www2.senado.leg.br/bdsf/bitstream/handle/id/137602/Constituicoes_Brasileiras _v3_1934.pdf?sequence=10\&isAllowed=y. Acesso em: 20 mai. 2020. 
PORTO, Walter Costa. Coleção Constituições brasileiras; v. IV - 3. ed. - Brasília: Senado Federal, Subsecretaria de Edições Técnicas, 2012. Disponível em: https://www2.senado.leg.br/bdsf/bitstream/handle/id/137571/Constituicoes_Brasileiras _v4_1937.pdf?sequence=9. Acesso em: 20 mai. 2020.

REZENDE, Élcio Nacur. Condomínio em Edifícios. Belo Horizonte, Del Rey: 2004.

TÁCITO, Caio. Coleção Constituições brasileiras; v. VII - 3. ed. - Brasília: Senado Federal, Subsecretaria de Edições Técnicas, 2012. Disponível: https://www2.senado.leg.br/bdsf/bitstream/handle/id/139952/Constituicoes_Brasileiras _v7_1988.pdf?sequence=10\&isAllowed=y. Acesso em 21 mai. 2020.

VENOSA, Sílvio de Salvo. Direito civil: reais - 19. ed. - São Paulo: Atlas, 2019.

Data da submissão: 09/06/2020

Data da primeira avaliação: $14 / 06 / 2020$

Data da segunda avaliação: 06/11/2020

Data da aprovação: 06/11/2020 